DOI: 10.2478/ausfm-2014-0020

\title{
Affective Realism and the Brand New Brazilian Cinema
}

\author{
Ramayana Lira \\ Universidade do Sul de Santa Catarina, Florianópolis (Brazil) \\ E-mail: ramayana.lira@gmail.com
}

\begin{abstract}
The restricted vocabulary that is often applied to discuss Contemporary Brazilian Cinema (aesthetics of hunger, marginality, national allegory, identity, bad consciousness) reveals a sort of generalizing approach that ignores the films' singularities and overlooks diverse affiliations. Works by young Brazilian filmmakers such as Irmãos Pretti, Eduardo Valente, Rodrigo Siqueira, and Sérgio Borges are a real challenge for the critic inasmuch as they escape this vocabulary and propose other questions. The films made by this young generation bypass traditional themes like urban violence and historical revisionism, thus demanding we rethink the political potency of Brazilian Cinema. Moreover, these films are not concerned with images of Brazil, pointing out to a post-identity politics that go beyond narratives of nation, class, or gender. This proposal aims at discussing this Brand New Brazilian Cinema (Novísssimo Cinema Brasileiro) and its affective realism. No longer a referent for a sociological truth about Brazilian society, realism is taken as something that the image does, i.e., as an affect that challenges the viewer's response-ability. This paper discusses two films (No meu lugar [Eye of the Storm, Eduardo Valente, 2009] and O céu sobre os ombros [The Sky Above, Sérgio Borges, 2010]) in order to assess the political relevance of the notion of realism, in its relationship with affect. ${ }^{1}$
\end{abstract}

Keywords: Brand New Brazilian Cinema (Novísssimo Cinema Brasileiro), realism, affect.

Retomada, "rebirth," is the label that is often used to describe a revitalization of Brazilian cinema after a crisis engendered by the extinction, in 1990, of Embrafilme, the most important funder for Brazilian cinema, controlled by the State. For half a decade film production in Brazil was a precarious affair. However, with a new legislation that allowed investments by private companies

1 I wish to thank CAPES (Coordenação de Aperfeiçoamento de Pessoal de Nível Superior) and Unisul (Universidade do Sul de Santa Catarina) for granting me funds and paid leave, respectively, for my postdoctoral reasearch at Centre for World Cinemas (University of Leeds). This article is a partial result of this research. 
through a system based on tax waiver, funding was again available and this new configuration not only favored the return of veteran filmmaker but it also created a space for the emergence of a new generation of directors (Walter Salles, Beto Brant, Fernando Meirelles, amongst many other). The Retomada, with its connotation of a renewal, may sound like a label that conveys the wrong idea of a uniform development of the film industry in Brazil since then. On the contrary - although film production has survived the near "blackout" of the early 1990's, the new form of funding via tax waiver has engendered at least two competing views among film critics and academics in Brazil: one, hurriedly celebrated the diversification of the production, an attitude that betrays an allegiance to market and state discourses; the other group, nonetheless, cautiously tried to avoid generalizations, instead focusing on each film in particular so as to extract possible relations that could eventually lead to a broader understanding of the contemporary scenario (Nagib 2002, Oricchio 2003, Debs 2004, Eduardo 2005). A decade and a half after this shift in the production cycle, the latter attitude is still a valid approach towards the comprehension of what is now being called the Brand New Brazilian Cinema - the films of young filmmakers, a second generation after the Retomada.

The expression Novíssimo Cinema Brasileiro (Brand New Brazilian Cinema) has been used by film critics in Brazil to describe the emergence of new directors but it would be misleading to say it bears any connection with Brazilian New Cinema (Cinema Novo), either in aesthetic or in political terms. Therefore, I'm using the expression to describe a new generation of filmmakers whose logic of production and circulation is relatively independent from industrial patterns. Some of the main aspects of the productions I am referring to here are: a) the films are mostly funded by public money, via tax waiver and direct financing coming from regional and national government, even though some of the films are completely independent of public money, adopting a totally independent attitude towards filmmaking; b) the films have a limited circulation in commercial circuits but they can be seen on public and cable TV (though not on primetime) or through alternative means of distribution; c) collective work is valued and shared authorship seems to put a dent on the figure of the author; d) the younger filmmakers are distancing themselves from the tradition of the struggling individual artist and of the director who speaks for a subaltern group (so closely associated with the 1960's and 1970's generations); e) as a consequence, contemporary films do not carry out totalizing discourses about individual or groups nor do they seem to reach any encompassing interpretation of the nation. 
Bypassing traditional themes in Brazilian cinematography such as urban violence and historical revisionism, the Brand New Brazilian Cinema demands we rethink our parameters and reassess their political potential. Furthermore, there seems to be an interest in images that are not "images of Brazil," indicating a post-identity politics which extravasates the contours of narratives of nation, class, race, and gender. This is a cinema that tends not to judge national "reality," opting for singular configurations, not allegorical ones. Although it is certainly not my ambition here to reach universal classifications, I want to trace some of the lines of force of this recent cinema and map a few points of escape from ubiquitous aesthetics and thematics. I identify a number of paradoxes that seem to feed the power of the image in these recent productions. Finally, I will briefly explore two films and finish with some methodological considerations, which, I hope, could be extrapolated to other cinemas.

In dialogue with audiovisual forms such as Hollywood genre film and exploitive TV news programs, a number of Brazilian films produced (roughly) between 1995 and 2010 have approached filmmaking through an allegedly "realist" standpoint and were saluted as a "rediscovery" of Brazilian society through which filmmakers exposed their critical social awareness. The use of the expressions "reality" and "reveal" is pervasive ${ }^{2}$ when referring to the approach described here, indicating a belief in the possibility of a true "revelation," of an objective expression of the world. Interestingly, in these circulating discourses about Brazilian films, the constructed "reality" of the film is taken as reality itself.

This problematic is addressed by a number of Brazilian scholars. Lúcia Nagib, for instance, in A Utopia no Cinema Brasileiro [The Utopia in Brazilian Cinema], explores The Trespasser (O Invasor, Beto Brant, 2002) saying that "O Invasor is a work of fiction. However, fiction can reveal more than the document through critical analysis. [...] Marina's character [...] is, perhaps, the film's main revelation as a symptom of late capitalism" (Nagib 2006, 177). The trope of the revelation is textually present. Moreover, even if Nagib's study of the fate of utopia in Brazilian cinema questions the way contemporary films deal with a national project, it eventually falls into a rather non-analytical praise of filmmakers like Walter Salles and Fernando Meirelles, who have an "international" career. She says: "If the Brazilian utopia is far from being realized, the Brazilian cinema utopia, at least in aesthetic terms, has taken place" (Nagib 2006, 21). The cinematic utopia: the

2 If we take the example of criticism about City of God (Cidade de Deus, directed by Fernando Meirelles and Katia Lund, 2002) in major periodic publications, we will see that the idea of the film's revelation of Brazilian society is present in Bravo! (July 2008), Revista de Cinema (November 2003), and Veja (October 2002), to name a few. 
recognition in a world market and the capacity to talk about violence and social convulsion in a "realist" way that is palatable for domestic and foreign audiences.

Esther Hamburger in Violência e pobreza no cinema brasileiro recente [Violence and Poverty in Recent Brazilian Cinema] analyses contemporary films that stress the visibility of poor, black dwellers of slums and periphery. She argues that when television and cinema bring these subjects to public attention, they intensify and stimulate a struggle for the control of visibility, for the definition of which subjects and characters will have audiovisual expression. Her approach, however, deals in term of stereotypes - how to correct or diversify the production of the images of poor violent people. What such truth-oriented perspective neglects is the fact that what is said to be "true" or not about a given community is not easily unveiled or wholly unproblematic.

A different account of the issues discussed here is given by Ismail Xavier. In $D a$ violência justiceira à violência ressentida (From Vengeful Violence to Resentful Violence), he argues that contemporary films resist the temptation to romanticize criminals like works in the past. The objective is to undermine the criminal's representativity (as a "spokesperson") in contrast with the violent characters of the past - mainly from the 1960's and 1970's - whose violence, although unequivocally criticized, still resounded as a justifiable response to social injustice. In this text, however, Xavier reveals a nostalgic reference to filmmakers of the past, as if they, like the criminals they produced on the screen, also held the legitimacy for social criticism. He states that "the 1960-70's metaphors [...] transformed the rifle into a camera, the left-winged filmmaker into a proto-guerilla confronting the media, and associated the aesthetics of violence to the wars of national liberation. The emphasis now changes and introduces a cinema whose unfoldings are more problematic because this modern instrument can corrode relationships and has unpredictable consequences (Xavier 2006, 66-7).”

What I find controversial about his argument is the qualification of recent works as "more problematic." This characteristic implies a "less" problematic past, which would portray violence and poverty in a more "adequate" way. To a certain extent, this is the same argument put forward by Ivana Bentes in her discussion of the "cosmetics of violence" as opposed to the "aesthetics of violence." Bentes defends that recent Brazilian films are resuming Cinema Novo themes such as poverty and violence, but without the political inflection of social denounce. For Bentes, contemporary cinema, on the contrary, makes a spectacle out of misery and violence, increasingly "consumed as a 'typical' or 'natural,' albeit helpless element” (Bentes 2007, 243). 
In her account, violence emerges as a new urban folklore, with its stories of crimes, massacres, and horrors. A new "brutality" that does not create spaces for complicity or mercy. Such random, meaningless violence eventually becomes a spectacle, representing the ultimate scission between favelas and the rest of the city. Moreover, there is no political discourse like in the 1960s (Bentes 2007, 249). What is different from the Cinema Novo context is the fact that presently the images of violence are also being appropriated by the marginalized subjects which conventional cinema demonizes. She concludes the article by stating that "there are many aesthetics of violence, with diverse ethics and consequences: affirmative, reactive, resistant, they can be symptoms and expression of forms of living, valuing and thinking” (Bentes 2007, 254). Although Bentes makes an important point by making reference to the different appropriations of images of violence, in these texts she stills reverberates the prominence of the "images of violence" as a "good" or "bad" representation.

When society and its vicissitudes are portrayed in films like City of God, Mango Yellow (Amarelo Manga, Claudio Assis, 2002), Carandiru (Hector Babenco, 2003), Lower City (Cidade Baixa, Sérgio Machado, 2005), and Elite Squad, and Elite Squad: The Enemy Within (Tropa de Elite and Tropa de Elite 2 - O Inimigo Agora É Outro, José Padilha, 2007 and 2010) they are contained in the representation of the urban space as a symptom of a naturalist impulse, an impulse that looks for legitimation by bringing to fore the "truth" about the "reality" in Brazil. In this sense, those films are reinforcing a consensus on the "appropriate" way to look at a given reality.

We can, for a final example, refer to Fatima Toledo's collaboration in the preparation of actors for City of God, Lower City, Elite Squad, among other contemporary films. In an interview to Piauí magazine entitled How Not To Be An Actor, Toledo defends that actors should not prepare for their roles according to Stanislavski's "What if...," which, according to her, is based on the "possibility of not being" (Toledo 2009, 54). She does not deny it that actor can "not be," but she argues that "being immediately awakens the sensorial. It's real! It's like in life!” (Toledo 2009, 54.) For Toledo, people are becoming desensitized and the expression "What if..." serves as a sort of security device that prevents people from acting. This search for the "real" is also present in her directorial debut, to come out in 2010, and which, according to the Piauí article, is provisionally entitled Sobre a Verdade (On Truth).

As we can see, there has a been a strong discourse in Brazilian film culture that appeals to a "real" constructed as "immediate," as if the characters were directly "denouncing" reality. Such search for the real - that can also be perceived in 
the increasing production of documentaries - is, however, more often then not, coated with an aesthetic or narrative varnish to prevent from a traumatic encounter. Realism becomes a way to achieve a certain general truth about society, whose evils are artfully denounced. The group of films I dub Brand New Brazilian Cinema has taken a different approach towards realism, which is now associated with the affective force of the image, renouncing the efforts to form a "critical" image that explains society to the viewers.

In an upper middle-class Rio de Janeiro home, a deliveryman and his girlfriend, the housemaid, are caught red-handed by the owner of the house as they were trying to steal from the family she works for. The deliveryman takes the man as a hostage. A police officer who happened to be passing by invades the house in an attempt to stop the crime. His rashness leads to the hostage's death. This is how Eye of the Storm, directed by Eduardo Valente in 2009, starts. The story, however, does not unfold in a straightforward way. What we have in the first minutes of the film are images of the police officer entering the house, but we do not get to know what is happening inside, for what we see is a long shot of the façade. Violence is only heard, as off-screen sounds indicate that something has gone terribly wrong.

We are then taken into the coexistence of three temporalities: a) Zé Maria (Márcio Vito), the police officer, deals with the consequence of his intervention immediately after the crime; b) the hostage's family returns after five years to the scene of the crime, as widow Elisa (Dedina Bernadelli) tries to finally come to terms with the death of her husband; and c) deliveryman Betão (Raphae Sil) and housemaid Sandra (Luciana Bezerra) in the weeks before the murder. This narrative organization molds the film into an account of the capacity to articulate memory. Characters have very few interactions in a diegetic present and the story is only intelligible through a "common," a "community" that is created by the film's materiality. Narrative dispersal, then, is not a function of space, but of time. Films like Crash (Paul Haggis, 2004) and Babel (Alejandro Gonzáles Iñarritú, 2006), for example, emphasize the (semi-)synchronous temporality of a geography that has to be re-imagined from narrative plots that are scattered across space. Eye of the Storm, on the contrary, stresses the re-articulation of disperse temporalities in the (semi-)homogenous space of Rio de Janeiro.

Furthermore, Valente's film explores narrative dispersion, but it is not so much concerned with the reconstruction of the truth about the crime, as a police report would be. Jacques Rancière $(1996,41)$ opposes politics to police - for him, police is a set of processes that produce aggregation and consent in societies, that organizes powers, the distribution of places and functions and the systems that legitimize 
such distribution. Although Eye of the Storm does not totally refuse narrative intelligibility, it still lends more force to the images per se instead of stressing a need to clarify/justify actions. What is most important are the intensities that traverse the characters and characterize the image: silences, replicated gestures (lit cigarettes, bodies lying on the couch, talks on the phone). The film's politics has a lot to do with how the film memory is constructed: it is figured in the tension, created in the cinematography, between dimming images and insistent glimmer of people and things. Memory thus becomes a fine cloud of fireflies. The image is a battlefield where dark endeavors to engulf forms and forms are made to redefine themselves following re-framings and camera movements.

Without dismissing Giorgio Agamben's theorization about the coming community as an arena of the "common being/ being common" (but still thought of in terms of a messianic kingdom), I would like to explore the fireflies metaphor following George Didi-Huberman's discussion of the image as something that resists, like fireflies resisting in their fight both against irrational dark and the blinding light of spectacle. For Didi-Huberman the image of the fireflies evokes signals emitted by intermittence, the very precarious like of a community of those who remain (Didi-Huberman 2011, 149) and that share with the image the fact that they are very little: remains or fissures (Didi-Huberman 2011, 87). As in Valente's film, we have the notion of a community whose memory/history is not a totalizing horizon but, rather, a function of glimmers.

It is no accident that one of the most remarkable reconfigurations in the film is the father figure. The totem, the speech of the law, is in crisis. The dead father reappears in dreams and in home video images, a ghost, or rather, as will-o-thewisp, ignis fatuus, cold light that emanates from the decomposition of organic matter. Zé Maria's relationship with his daughter is nearly incestuous and is threatened by his inability to deal with the consequences of the crime. Betão's father figure is his decadent alcoholic uncle. The film seems to suggest the dissolution of central figures, undertaken by both the narrative's agency and by the representation of the redistribution of social roles.

One of the most telling instances of the working of affects in Eyes of the Storm is, in fact, an apparently unimportant scene with Betão and his uncle. As in other sequences in the film there is little verbalization. The conversation is actually quite awkward, vacillating. The topics are never fully developed as uncle and nephew seem to fumble with words. The scene is marked by a graceful interaction that is not meant to be functional in the narrative but that exudes affect. Even when portraying unprivileged people, the film does not focus on description of 
their social status or comment on injustice; on the contrary, it explores pauses and shadows, relying on affect in order to engage the spectator.

At the end of Eye of the Storm a song works as a post-scriptum. The lyrics say: "lá onde tudo acaba / longe da fala / tudo que afeta / é aqui" (there where it all ends / away from speech / all that affects / is here). Here we may have a hint that helps us understand the original title in Portuguese: No Meu Lugar can be literally translated as "in my place." As the song suggests, there is a place "where it all ends" and where "all that affects" is. This is the place where affect opens up the present for the reconstruction of memory through the very subtle, ever fragile glimmer of the image and of the characters, who are not agents in a narrative that emanates from the centre. In fact, they disperse events in affects which are small lights, forms that emerge in spite of all. This is the fireflies' movement, the paradoxical image that unfolds between the memory that fades and the memory that resists.

Another paradoxical image can be seen in a film released shortly after Eye of the Storm. In it, three lives look through a bus window. Three affection-images of characters who roam through the city. We watch them with apprehension, trying to find a scene, a narrative line that would situate them. And we are denied that. What we are given are instants (once again, glimmering) of lives embedded in subtle everyday plots. Their lightness is unbearable. That is the burden of The Sky Above, directed by Sérgio Borges.

The Sky Above portrays the lives of three lower middle-class people - a transexual prostitute and academic, a hare krishna telemarketing operator who loves football, and a disillusioned writer from Congo who has a disabled child. The multilayered characters are not portrayed as exotic/victimized others. In a way, Borges's films radicalize the performative immanence of film as images and lives are completely imbricated. The static shots with few re-framings leave a lot of space for the subtle variations in gestures and speech. The film is not about giving voice to the marginalized other; rather, it is concerned with the presentation of the intensities that form the lives in question. There is nothing programmatic, or "critical" in the sense of an impulse to explicate some kind of social evil.

Elena del Rio comments about performance that "in its fundamental ontological sense, performance gives rise to the real. While representation is mimetic, performance is creative and ontogenetic" (del Rio 2008, 4). So performances in the contemporary Brazilian cinema I am referring to are not a matter of registering the ephemeral, but of creating something new, new affects, new worlds. In The Sky Above the actors' bodies are extracting something new from the image in a process that Elena del Rio summarizes as such: "Thus the body simultaneously figures 
as a normative structure regulated by binary power relations (on a molar plane of formed subjects and identities) and as an excessive, destabilizing intensity responsive to its own forces and capacities (on a molecular plane of impersonal and unformed becomings)" (del Rio 2008, 9). Del Rio also dismisses the idea that the performative force of films would be restricted to certain genres or filmic forms. She says: "Rather than depending upon a particular kind of film (a stabilizing condition inimical to the very disruptive function of the affective-performative), the eruption of affective-performative moments is a matter of a constantly fluctuating distribution of degrees of intensity between two series of images: those belonging to explainable narrative structures, and those that disorganize these structures with the force of affective-performative events" (del Rio 2008, 15).

Therefore, both fiction and documentary films can be affected by the forces of performance.

Indeed, if we take some of the recent documentary films produced by young filmmakers in Brazil, we will be able to see performance in the very core of a profound critique of truth. These films allow us to observe that not only does performance disorganize narrative strictures/structures, as proposed by Del Rio, but it is also a function of the image: we could say that the image itself is "performing" something. The Sky Above insists on static framing (we rarely see re-framings or de-framings) and its mise-en-scène values the subtle variations in the characters' lives, never the grand gestures. Blocs of everyday situations are presented without narrative coherence, as if the film were accepting life's irresistible contingency.

But what is even more troubling in Borges's film is the fact that these situations were staged by the characters for the camera. The film's realism is, then, the reality of those performances, of their coming to the world in a temporality that the film preserves without submitting it to a functionalist logic. The strength of its image in the very vaporous state of these lives. In this movement, world and image merge. And that brings the second paradox: the paradox of the critical potential of that which is rarefied.

These are some of the possible lines of force of a realism that is being refashioned in recent Brazilian films. These works are marked by an in-betweenness at the intersection of the impulse to keep a certain distance in order to see the world and to be immersed in it, in its intensities. They make us face paradoxes but don't immobilize us; on the contrary, they com-move us with their contradictory forces. The question that underlies this recent production is exactly how to grasp political configurations from such dispersive, fragmented, diffuse forces. Dispersion seems 
to evoke dissolution. Subtlety can look like weakness, impotence. However, what interests me in the study of the politics of affects in the Brand New Brazilian Cinema are the connections between these affects and the complex social processes and issues like the reconstruction of memory and the possibility of creating a world along with the image are examples of such connections.

Considering that representation works by means of immobilization, and spatialization, it conveniently becomes a process through which we "interpret" the always implied referent. The analogies and correspondences it creates between elements are produced to the detriment of their differences, movements and changes. However, we can argue that the affective potential of film is not that it resembles the objects it represents (the iconic nature of cinema). This potential would lie in the capacity of the film to defy the limitations of the intellect, drawing us not to a chain of action and reaction, but to a zone of indeterminacy between perception and action, one that leaves us with no straight forward "response" to the images.

In this perspective, the body no longer reassures reality, identities or self on the contrary, it is exposed to variations, fluxes, and mutations. This much more complex understanding of what a body can do surpasses the widespread simplification that "the body thinks". What this platitude fails to perceive is that the variations and intensities that traverse the body force us to think about something that, from its origins, belongs to the sphere of the unthinkable. The body makes us think about that which is not thinkable.

Affects emerge in the cinema I am talking about both in the creative encounters in the filmmaking processes and in the reconfigurations of relations between characters that suggest new models for being together. And it is affect that is at stake when our response-ability (to use Marco Abel's terminology) is at stake as spectators. Cinema may thus become, as Nicole Brenez puts it, "that creature haunted by heterogeneity which, more than knowing itself, prefers to verify that something else is still possible (a body, a friend, a world)" (1997).

\section{References}

Abel, Marco. 2007. Violent Affect: Literature, Cinema, and Critique after Representation. Lincoln: University of Nebraska Press.

Bentes, Ivana. 2007. Sertões e Favelas no Cinema Brasileiro Contemporâneo: Estética e Cosmética da Fome [Barrens and Slums in Contemporary Brazilian Cinema: Aesthetics and Cosmetics of Hunger]. Alceu. vol. 8 no. 15: 242-255. 
Brenez, Nicole. 1997. The Ultimate Journey: Remarks on Contemporary Theory. Screening the Past 2. http://www.latrobe.edu.au/screeningthepast/reruns/ brenez.html. Last accessed at 01.03.2013.

Debs, Sylvie. 2004. El cine brasileño de la reativación [Brazilian Cinema Revival]. Cinémas D’Amérique Latine, no 12. Paris-France: ed. Press Universitaires Du Mirail (PUM).

Del Rio, Elena. 2008. Deleuze and the Cinemas of Performance: Powers of Affection. Edinburgh: Edinburgh University Press.

Didi-Huberman, Georges. 2011. Sobrevivência dos vaga lumes. Belo Horizonte: UFMG.

Eduardo, Cléber. 2005. Fugindo do inferno - A distopia na redemocratização [Escaping Hell - the Re-Democratization Dystopia]. In Cinema Brasileiro 1995-2005: revisão de uma década [Brazilian Film 1995-2005: a Review of a Decade], ed. Daniel Caetano. Rio de Janeiro: Azougue Editorial.

Hamburger, Esther. 2007. Violência e Pobreza no Cinema Brasileiro Recente [Violence and Poverty in Recent Brazilian Cinema]. Novos Estudos. no 79: 113-120.

Nagib, Lúcia. 2002. O Cinema da Retomada: depoimento de 90 cineastas dos anos 90 [The Cinema of Recovery: Testimony of 90 Filmmakers of the 90s]. São Paulo: Editora 34.

Nagib, Lúcia. 2006. A Utopia no Cinema Brasileiro [Utopia in Brazilian Cinema]. São Paulo: Cosac \& Naify.

Oricchio, Luiz Zanin. 2003. Cinema da Retomada alimenta o mito da diversidade ["Cinema da Retomada” feeds the myth of diversity]. Revista de cinema. no. 35 (March). São Paulo: Ed. Krahô.

Rancière, Jacques. 1996. O desentendimento: política e filosofia [Disagreement: Politics and Philosophy]. São Paulo: Ed 34.

Toledo, Fátima. 2009. Como não ser ator [How Not to Be an Actor]. Piaui. no. 28 (January): 54-58.

http://revistapiaui.estadao.com.br/edicao-28/questoes-de-interpretacao/comonao-ser-ator. Last accessed at 31. 07. 2013.

Xavier, Ismail. 2006. Da Violência Justiceira à Violência Ressentida [From Vengeful Violence to Resentful Violence]. Ilha do Desterro. no. 51: 55-68. 